\title{
THE EFFICACY OF FUNGICIDES AND BIOCONTROL AGENTS FOR CONTROL OF GLOMERELLA CINGULATA ON SATSUMA MANDARINS
}

\author{
K.R. EVERETT ${ }^{1}$ and T. MACHIN ${ }^{2}$ \\ ${ }^{1}$ HortResearch, Private Bag 92169, Mt Albert, Auckland, New Zealand \\ ${ }^{2}$ HortResearch, P.O. Box 23, Kerikeri, New Zealand \\ Corresponding author: Keverett@hortresearch.co.nz
}

\begin{abstract}
Six products were tested for efficacy for control of anthracnose, caused by Glomerella cingulata, on Satsuma mandarins. There were three conventional fungicides (folpet, copper hydroxide and mancozeb) and three new biological control agents $\left(\right.$ Botryzen $^{\circledR}$, Serenade $^{\circledR}$ and an experimental product, HR42). Botryzen ${ }^{\circledR}$ is a saprophytic fungus that competitively colonises plant material also invaded by pathogenic fungi, Serenade ${ }^{\circledR}$ is a saprophytic bacterium (Bacillus subtilis) that produces a diffusable substance that inhibits fungal pathogens, and HR42 is a saprophytic bacterium with a similar mode of action to Serenade ${ }^{\circledR}$. Application of Serenade ${ }^{\circledR}$, HR42 and mancozeb significantly $(\mathrm{P}<0.005)$ reduced symptoms (speckles) ascribed to $G$. cingulata. Isolations of Bacillus subtilis from leaf discs of Serenade ${ }^{\circledR}$-treated trees showed that leaves were successfully colonised by this bacterium up to at least a week after application. Blotches that could not be removed appeared on fruit treated with Botryzen ${ }^{\circledR}$ and copper hydroxide. For Botryzen ${ }^{\circledR}$, this may have been due to interaction with a surfactant.
\end{abstract}

Keywords: citrus, anthracnose, fungicide, disease control, Citrus reticulata.

\section{INTRODUCTION}

Satsuma mandarins (Citrus reticulata) can be affected by a number of pre-harvest plant diseases, namely citrus scab (verrucosis), anthracnose, melanose and botrytis. Colletotrichum gloeosporioides, the anamorph of Glomerella cingulata, causes anthracnose disease. Fruits may be disfigured by 'tearstain' lesions on the peel, or they may undergo severe rotting, with the formation of dark sunken lesions (Whiteside et al. 1988; Snowdon 1990; Fullerton et al. 2001; Taverner et al. 2002). One application of folpet at the recommended rate (Table 1) is the industry recommendation to control G. cingulata in New Zealand citrus (K.R. Pyle, pers. comm.). However, the effectiveness of this one application on $G$. cingulata has not been established and adoption of this practice is based on anecdotal evidence. Folpet is expensive, and there are cheaper alternatives that could be just as efficacious, e.g. copper and mancozeb (Fullerton et al. 2001). In addition, recently commercialised fungicides are now available, such as the biological control agents Serenade ${ }^{\circledR}$ and Botryzen ${ }^{\circledR}$. The trial described in this paper compared the efficacy of these products. An experimental HortResearch biological control agent (HR42) was also included.

\section{Fungicide application}

\section{METHODS}

The trial was on a Satsuma mandarin orchard block in Kerikeri (Kwan Mandarins, Inlet Road, Kerikeri) with a previous history of G. cingulata infections. Six products were tested viz., folpet, copper hydroxide, mancozeb, Serenade ${ }^{\circledR}$, Botryzen ${ }^{\circledR}$ and 
HR42 (Table 1). The efficacy of these products was compared with unsprayed trees. Each spray treatment was applied to five replicate trees using a randomised block design. Products were applied at recommended rates (Table 1) on two occasions, immediately after flowering (11 February 2004) and then at early fruit set (5 March 2004) using a pressurised hand gun sprayer. Latron ${ }^{\circledR}$ B-1956, a phthalic glycerol alkyd resin and butyl alcohol with surfactant properties, was added at $3 \mathrm{ml} / 60$ litres to all treatments except the unsprayed.

TABLE 1: Rates of active ingredients and total volume of solutions applied to five trees per treatment of Satsuma mandarins in a field trial.

\begin{tabular}{llcl}
\hline Product & Active ingredient (a.i.) & $\%$ a.i. & Rates used (a.i./100 litres) \\
\hline HR42 & bacterial cells & 100 & $10^{8} \mathrm{cfu} / \mathrm{ml}^{1}$ \\
Phaltan ${ }^{\circledR}$ & folpet & 50 & $125 \mathrm{~g}$ \\
Serenade $^{\circledR}$ & Bacillus subtilis QST713 & 10 & $5 \times 10^{8} \mathrm{cfu} / \mathrm{ml}$ \\
Blue Shield $^{\circledR}$ DF & copper hydroxide & 50 & $125 \mathrm{~g}$ \\
Dithane ${ }^{\circledR}$ RF & mancozeb & 75 & $157.5 \mathrm{~g}$ \\
Rainshield & & & \\
Botryzen $^{\circledR}$ & non-pathogenic fungus & Not stated $467 \mathrm{~g}$ (product) \\
\hline
\end{tabular}

\section{Sampling peduncles and leaf discs}

Peduncles were collected 7 days after each spray application, on 18 February and 12 March. Leaf discs ( $1 \mathrm{~cm}$ diameter, 20 per plant, sampled 5 per quadrant from each of 4 quadrants at north, south, east and west equidistant around the tree) were only sampled after the final spray application on 12 March. A total of 35 trees were sampled on each occasion. Peduncles and leaf discs were transported in plastic ziplock bags from Kerikeri to Mt Albert on the same day.

The next day peduncles were placed in a humidified environment, 20 per chamber. The humidified environment consisted of a sterilised glass Petri plate containing a $70 \mathrm{~mm}$ diameter disc of Whatman No. 1 filter paper moistened with sterile reverse osmosis water. Peduncles were examined with an illuminated magnifying glass (Gartner Superlux Ltd. Model LSX) 2 and 3 weeks after placement in the humid conditions and $G$. cingulata quantified by counting the number of peduncles infected out of the total number of peduncles collected.

Leaf discs were sterilised (20 at a time) by rinsing in 95\% ethanol for 1 min, sodium hypochlorite (12.2 g/litre sodium hypochlorite) for $3 \mathrm{~min}$ and sterile reverse osmosis water for $30 \mathrm{sec}$. Leaf discs were then dried on sterile blotting paper and placed on Difco® Potato Dextrose Agar in Petri plates (10 discs per plate) (Petrini 1986). After 7-14 days, the number of leaf discs (out of 20) from which C. gloeosporioides grew was counted. Leaf discs from which Bacillus subtilis colonies grew were also counted.

\section{Fruit assessments}

Fruit were examined for disease symptoms and for any signs of phytotoxicity, when green on 31 March and after the colour had changed to orange on 15 April. There were three main symptom types described and assessed on fruit. The first of these was attributed to $G$. cingulata and consisted of localised brown spotting lesions about $1 \mathrm{~mm}$ diameter in green fruit. These symptoms developed into more widespread brown lesions about 1-3 mm diameter on mature orange fruit. Another symptom, termed blotches, consisted of more diffuse green spots about 5-10 $\mathrm{mm}$ diameter. The third symptom type, termed grey/brown lesions, consisted of discrete grey spray deposits that developed into large brown sunken lesions (10-50 mm diameter) that could not be removed.

Symptoms were scored as a percentage of total fruit surface area covered, and 30 randomly selected fruit per tree were assessed, non-destructively. 


\section{Statistical analysis}

The generalised linear model function of MINITAB (version 9.0) was used for data analysis. Means were separated using Dunnett's test at $\mathrm{P}<0.05$. The linear regression function of Origin (version 7.5) was used to test the relationships between leaf disc and peduncle isolations and fruit rots.

\section{Sampling peduncles and leaf discs}

\section{RESULTS}

There were no significant treatment differences for the number of peduncles infected with $G$. cingulata at either sampling time (Table 2).

The number of leaf discs from which $G$. cingulata was isolated was significantly lower from leaf discs of Serenade ${ }^{\circledR}$-treated trees than all other treatments (Table 2). The active ingredient of Serenade ${ }^{\circledR}$, the bacterium Bacillus subtilis, was re-isolated from almost all leaf discs from Serenade ${ }^{\circledR}$-treated trees (Table 2). Leaf discs from trees treated with Botryzen ${ }^{\circledR}$ and HR42 yielded significantly more G. cingulata than did leaf discs from Serenade ${ }^{\circledR}$ treated trees, but there were no other significant differences.

TABLE 2: Mean number of peduncles infected with $G$. cingulata (out of 20) and isolations of $G$. cingulata and $B$. subtilis from leaf discs expressed as a percentage ( 20 per tree, five trees per treatment). Treatments were applied on 11 February and again on 5 March, with samples being taken 7 days after spraying for peduncles, and 7 days after the final spray for leaf discs.

\begin{tabular}{lcccccc}
\hline & \multicolumn{3}{c}{ Peduncles } & \multicolumn{4}{c}{ Leaf discs - 12 March } \\
\cline { 2 - 7 } & 18 Feb & $12 \mathrm{Mar}$ & \multicolumn{2}{c}{ G. cingulata } & B. subtilis \\
\hline folpet & 12.8 & 4.4 & 33 & $\mathrm{ab}$ & 31 & $\mathrm{~b}$ \\
copper hydroxide & 10.4 & 1.6 & 30 & $\mathrm{ab}$ & 35 & $\mathrm{~b}$ \\
mancozeb $^{1}$ & 14.2 & 1.0 & 29 & $\mathrm{ab}$ & 12 & $\mathrm{~b}$ \\
Serenade $^{\circledR}$ & 9.6 & 3.4 & 5 & $\mathrm{c}$ & 97 & $\mathrm{a}$ \\
Botryzen $^{\circledR}$ & 12.2 & 2.8 & 57 & $\mathrm{a}$ & 13 & $\mathrm{~b}$ \\
HR42 $^{\circledR}$ & 12.0 & 1.8 & 47 & $\mathrm{a}$ & 30 & $\mathrm{~b}$ \\
Unsprayed & 10.4 & 0.6 & 31 & $\mathrm{ab}$ & 29 & $\mathrm{~b}$ \\
SED $^{2}$ & 2.3 & 1.5 & 10.8 & & 16.1 & \\
P-value & n.s. $^{3}$ & n.s. & 0.003 & & $<0.001$ & \\
\hline
\end{tabular}

${ }^{1}$ Numbers in columns followed by the same letter are not significantly different according to Dunnett's test at $\mathrm{P}<0.05$.

${ }^{2} \mathrm{SED}=$ Standard error of difference.

${ }^{3}$ n.s. $=$ not significant.

\section{Fruit symptoms}

There were significantly fewer $G$. cingulata symptoms on fruit from all treatments, except copper hydroxide sprayed trees, than on fruit from the unsprayed control trees when assessed one week after the first spray application (Fig. 1a). One week after the second spray application, fruit from trees treated with mancozeb, Serenade ${ }^{\circledR}$ and HR42 had significantly fewer G. cingulata symptoms than fruit from untreated trees (Fig. 1b).

There were no significant treatment differences for blotches when assessed one week after the first spray application, but there were significantly more blotches on fruit from copper hydroxide sprayed trees when fruit were assessed one week after the second spray application (Table 3 ).

There were significantly more grey/brown lesions on fruit from Botryzen ${ }^{\circledR}$ treated trees on both assessment dates (Table 3). Attempts to wash the grey/brown lesions off harvested fruit were unsuccessful. 
There was no significant relationship between isolations from leaf discs and peduncles and fruit rots as tested by linear regression.
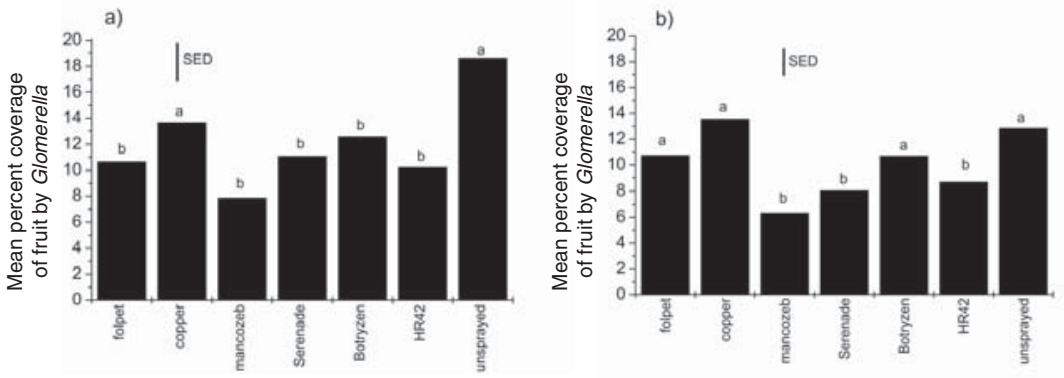

FIGURE 1: Mean percent coverage of Satsuma mandarin fruit by G. cingulata symptoms (30 fruit assessed per tree, 5 trees per treatment) with standard error of mean (SED). Bars with the same letter are not significantly different according to Dunnett's test $(P<0.05)$. Fruit were assessed (a) on 31 March after the first spraying and (b) on 15 April after the second spraying.

TABLE 3: Mean percent coverage of Satsuma mandarin fruit by blotches and grey/brown lesions.

\begin{tabular}{|c|c|c|c|c|c|c|}
\hline \multirow[b]{3}{*}{ folnet } & \multicolumn{2}{|c|}{ Blotches } & \multicolumn{4}{|c|}{ Grey/brown lesions } \\
\hline & $31 \mathrm{March}$ & 15 April & $31 \mathrm{Mar}$ & & $15 \mathrm{Apr}$ & \\
\hline & 0.07 & $0.03 \quad b^{1}$ & 0 & $\mathrm{~b}$ & 0 & $\mathrm{~b}$ \\
\hline copper hydroxide & 0.3 & 1.83 & 0 & $\mathrm{~b}$ & 0 & $b$ \\
\hline mancozeb & 0.03 & 0.01 & 0 & $\mathrm{~b}$ & 0 & $b$ \\
\hline Serenade ${ }^{\circledR}$ & 0.25 & 0.45 & 0 & $\mathrm{~b}$ & 0 & $\mathrm{~b}$ \\
\hline Botryzen $^{\circledR}$ & 0 & 0 & 51.3 & a & 25.9 & a \\
\hline HR42 & 0.28 & 0.01 & 0 & $\mathrm{~b}$ & 0 & $\mathrm{~b}$ \\
\hline Unsprayed & 0.03 & 0.14 & 0 & b & 0 & b \\
\hline $\mathrm{SED}^{2}$ & 0.15 & 0.16 & 2.5 & & 0.82 & \\
\hline P-value & n.s. ${ }^{3}$ & $<0.0001$ & $<0.0001$ & & $<0.0001$ & \\
\hline
\end{tabular}

${ }^{1}$ Numbers in columns followed by the same letter are not significantly different according to Dunnett's test at $\mathrm{P}<0.05$.

${ }^{2} \mathrm{SED}=$ Standard error of difference.

${ }^{3}$ n.s. $=$ not significant.

\section{DISCUSSION}

Application of mancozeb, Serenade ${ }^{\circledR}$ and HR42 significantly reduced the brown spotting lesions described as a symptom of $G$. cingulata in this spray trial. After the second of the two sprayings this disease symptom appeared to decline in some treatments. This can either be attributed to severely infected fruit dropping from the tree, or to difficulties of identifying these symptoms once fruit had changed colour from green to orange. HR42 is an unregistered and unformulated product that is not currently commercially available and therefore cannot be recommended for control. However, because it was as effective as the best fungicide tested, HR42 shows potential for commercialisation. 
Copper hydroxide and Botryzen ${ }^{\circledR}$ caused symptoms termed blotches and grey/brown lesions respectively, and did not control G. cingulata. The grey/brown symptoms may have been due to incompatibility of Botryzen ${ }^{\circledR}$ with the surfactant used, as Latron is not currently recommended for this use (Anon. 2005). Folpet also did not significantly reduce G. cingulata symptoms. None of these three treatments can be recommended for control of disease caused by G. cingulata.

The number of peduncles and leaf discs infected with $G$. cingulata was not related to fruit symptoms when analysed using linear regression, and there were no significant differences between treatments apart from for Serenade ${ }^{\circledR}$-treated trees. Other work with Colletotrichum acutatum on avocado has shown a clear relationship between infected leaf discs and final fruit rots when different orchards were compared (Everett et al. 2003). It is possible that tree to tree variation on the single citrus orchard used in the present study was too great to find a significant relationship. Alternative explanations are that latent infections are not important in the G. cingulata disease of citrus, or that in citrus, leaf inoculum is not related to fruit inoculum. This aspect requires further investigation.

Isolations of Bacillus subtilis from leaf discs from Serenade ${ }^{\circledR}$-treated trees showed that leaves were successfully colonised by this bacterium up to at least a week after application. However, despite having the lowest isolation of G. cingulata from leaf discs, application of Serenade ${ }^{\circledR}$ did not provide significantly better control of the fruit symptoms than HR42 and mancozeb. As isolations of G. cingulata from leaf discs were unrelated to fruit disease, this result is not unexpected.

\section{ACKNOWLEDGEMENTS}

Brad Davies and Kwan Industries for use of the orchard, and Nihal deSilva for statistical advice. NZCGI/SFF for funding.

\section{REFERENCES}

Anon. 2005. Botry-zen ${ }^{\circledR}$ Best Practice- Grapes. http://www.botryzen.co.nz/index2.htm (Accessed 2 June 2005).

Everett KR, Rees-George J, Parkes SL, Johnston PR 2003. Predicting avocado fruit rots by quantifying inoculum potential in the orchard before harvest. Proceedings of the $5^{\text {th }}$ World Avocado Congress. Granada-Malaga, Spain. Pp. 601-606.

Fullerton RA, Tyson JL, Sale PR 2001. Citrus diseases. In: Growing citrus in New Zealand. A practical guide. Mooney P ed. HortResearch and New Zealand Citrus Growers Incorporated. Pp. 97-107.

Petrini O 1986. Taxonomy of endophytic fungi in aerial plant tissues. In: Fokkema NJ, van den Heuvel J ed. Microbiology of the phyllosphere. Cambridge University Press, Cambridge. Pp. 175-187.

Snowdon AL 1990. A colour atlas of post-harvest diseases and disorders of fruits and vegetables. Volume 1: General Introduction and Fruits. Wolfe Scientific Ltd. 302 p.

Taverner P, Tugwell B, Wild B 2002. A guide to the common postharvest diseases and disorders of navel oranges and mandarins grown in inland Australia. South Australia Research and Development Institute, Horticultural Research and Development Corporation. $6 \mathrm{p}$.

Whiteside JO, Garnsey SM, Timmer LW ed. 1988. Compendium of citrus diseases. APS Press, St Paul, Minnesota, USA. 80 p. 